\title{
Neoglacial trends in diatom dynamics from a small alpine lake in the Qinling mountains of central China
}

\author{
Bo Cheng $^{1}$, Jennifer Adams ${ }^{2}$, Jianhui Chen ${ }^{3}$, Aifeng Zhou ${ }^{3}$, Qing Zhang ${ }^{3}$, and Anson W. Mackay ${ }^{4}$ \\ ${ }^{1}$ College of Urban and Environmental Science, Central China Normal University, Wuhan 430079, China \\ ${ }^{2}$ Department of Biology, University of Waterloo, Waterloo, ON, Canada \\ ${ }^{3}$ Key Laboratory of West China's Environmental System (Ministry of Education), \\ College of Earth and Environmental Sciences, Lanzhou University, Lanzhou 730000, China \\ ${ }^{4}$ Environmental Change Research Centre (ECRC), Department of Geography, \\ University College London (UCL), London WC1E 6BT, UK
}

Correspondence: Aifeng Zhou (zhouaf@lzu.edu.cn) and Anson W. Mackay (a.mackay@ucl.ac.uk)

Received: 9 July 2019 - Discussion started: 5 August 2019

Revised: 6 January 2020 - Accepted: 28 January 2020 - Published: 17 March 2020

\begin{abstract}
During the latter stages of the Holocene, and prior to anthropogenic global warming, the Earth underwent a period of cooling called the neoglacial. The neoglacial is associated with declining summer insolation and changes to Earth's surface albedo. Although impacts varied globally, in China the neoglacial was generally associated with a cooler climate and an attenuated Asian summer monsoon. Few studies in central China, however, have explored the impact of neoglacial cooling on freshwater diversity, especially in alpine regions. Here we take a palaeolimnological approach to characterise multi-decadal variability in diatom community composition, ecological guilds, and compositional turnover over the past 3500 years from the alpine Yuhuang Chi lake on Mount Taibai in the Qinling mountains. Diatoms in the high-profile guild dominate much of the record from 3500 to $615 \mathrm{cal} \mathrm{BP}$, which suggests that few nutrients in the lake were limiting overall, and disturbance and herbivory were likely low. After 615 cal BP, low-profile and planktic guild diatoms increase, suggesting greater turbulence in the lake, alongside a decline in available nutrients. Diatom turnover highlights periods in the lake history when deterministic processes structured diatom communities. For example, an abrupt decline in turnover is coincident with the shift from high- to low-profile diatoms at $615 \mathrm{cal} \mathrm{BP}$, and this is likely due to the onset of the Little Ice Age in the region. We suggest that Yuhuang Chi lake became more shallow during peak regional aridity, which led to the short-lived community restructuring observed in the record.
\end{abstract}

\section{Introduction}

Alpine ecosystems are some of the most sensitive to changing climate, due in part to elevation-dependent warming, i.e. the amplification of warming at higher altitudes (Yan and Liu, 2014; Pepin et al., 2015). Understanding how highaltitude ecosystems respond to changing climate is a matter of urgency, because not only do these regions act as "water towers" supplying water to huge populations downstream (Messerli et al., 2004; Buytaert et al., 2017) but they also provide habitats to many iconic species that are classified by the IUCN (International Union for Conservation of Nature) as being vulnerable (Fan et al., 2014). Alpine freshwaters have multiple ecosystem functions (Messerli et al., 2004; Buytaert et al., 2017) and provide many ecosystem services such as freshwater regulation and habitat provision (GrêtRegamey et al., 2012). Their multifunctionality depends on local species communities and how species vary through space and time (beta diversity) and are driven by ecosystem properties, environmental gradients, and species interactions (Korhonen et al., 2010).

Beta diversity links biodiversity at regional and local scales, and it may take the form of non-directional variation or directional turnover (Anderson et al., 2011). Long-term records of beta diversity commonly focus on the amount of compositional turnover over time, which provides important information on ecosystem functioning (Birks, 2007). For example, estimating species turnover assumes that species are 
lost and gained over time in response to resource availability, competition, historical events, and environmental factors (Korhonen et al., 2010) over both recent (Smol et al., 2005) and long timescales (Leprieur et al., 2011). However, because the concept of beta diversity has so many meanings to different disciplines, we take the approach of Felde et al. (2020) and just focus on directional compositional turnover, which is appropriate for palaeolimnological datasets from a single lake.

Natural archives are an important resource for reconstructing past environments where long-term historical and/or instrumental records are either scarce or absent. In central China, speleothems provide exceptional, high-resolution records of monsoon intensity, allowing for periods of multiannual and multi-decadal drought to be determined (Wang et al., 2005). Yet there are relatively few studies (Liu et al., 2017) which have explored multi-decadal records of biodiversity change over similar timescales, leaving a fundamental gap in understanding as to how biodiversity in freshwater ecosystems, especially at higher altitudes, responds to periods of climate variability. Reconstructing the impacts of past climate on freshwater ecosystems is fundamental to understanding how freshwater biodiversity may respond to future climate, especially during periods of rapid change. Here we focus on the neoglacial, which spans at least the past ca. 3500 years.

The neoglacial, characterised by increasingly cooler temperatures, follows on from globally warmer temperatures of the early to mid-Holocene. The extent of cooling varied regionally, being most pronounced in the extratropical Northern Hemisphere (Marcott et al., 2013). The most important driver of Northern Hemisphere cooling was declining summer insolation (Marcott et al., 2013) in conjunction with changes in albedo on the Earth's surface, which was linked to feedbacks from vegetation and snow/ice. In China, the neoglacial resulted in the persistent decline in monsoon intensity in southern China (Wang et al., 2005) and a rapid decline in precipitation in northern China (F. Chen et al., 2015), leading to increased aridity and major shifts in vegetation communities (Zhou et al., 2010). Superimposed on the insolation-driven neoglacial were notable periods of sub-Milankovitch centennial-scale climatic events (e.g. Mayewski et al., 2004; Mann et al., 2009; Wanner et al., 2014), including the $2800 \mathrm{BP}$ event (Hall et al., 2004), the Medieval Climatic Anomaly (MCA) (ca. 1000-1300 CE) and the Little Ice Age (LIA) (ca. 1300-1850 CE). The latter two events are well expressed throughout China; medieval temperatures were generally warmer than the following centuries spanning the LIA (Cook et al., 2013; J. Chen et al., 2015). However, while the LIA generally resulted in periods of aridity (e.g. Wang et al., 2005; Tan et al., 2011; F. Chen et al., 2015), in-depth research highlights a more heterogenous response across China (e.g. Cook et al., 2010), with some central and southern regions becoming wetter due to inter- plays between the westerly jet stream and the Asian summer monsoon (ASM) (Tan et al., 2018).

Freshwater ecosystems in the Qinling mountains of central China provide natural capital and ecosystem services for local and regional populations, and understanding the impact of monsoon variability on ecosystem functioning has the potential to add insight into how freshwater biodiversity may respond to future climate change and predicted increases in mean annual precipitation (Guo et al., 2017). In this study, we reconstruct neoglacial trends in diatom community composition, their ecological guilds, and compositional turnover at a multi-decadal resolution over the past 3500 years.

\section{Study region}

The Qinling mountains are widely recognised for their conservation importance and as a biodiversity hotspot; they are a refuge for many Tertiary plants (Zhang et al., 2017) and vulnerable species such as the Giant Panda (Fan et al., 2014). The region is climatically very sensitive, as it separates the northern subtropical zone of China from the country's central warm-temperate zone (Fig. 1). Mount Taibai $\left(34^{\circ} \mathrm{N}, 108^{\circ} \mathrm{E}\right.$; $3767 \mathrm{~m}$ ) is the highest mountain in the range, with a timberline at ca. $3370 \mathrm{~m}$ and treeline at ca. $3600 \mathrm{~m}$ (Liu et al., 2002). The mountain is classified as a glacial heritage site, because Quaternary glaciations are well preserved, especially the last glaciation (Yang et al., 2018). On Mount Taibai there are several clusters of cirque lakes, and our study site, Yuhuang Chi (YHC) lake, is found in one of these clusters. It is a cirque and moraine lake at $3370 \mathrm{~m}$ a.s.l., placing it in the Larix forest - subalpine meadow ecotone. Specifically, Larix chinensis Beissn grows in podzolic soils between 2000 and $3500 \mathrm{~m}$, and it is associated with a cold, arid climate. Regional annual average temperature is below $8^{\circ} \mathrm{C}$ and annual precipitation is ca. $840-960 \mathrm{~mm}$. Yuhuang Chi lake has a maximum depth of $21.5 \mathrm{~m}$ and an area of ca. $23600 \mathrm{~m}^{2}$. No shoreline macrophytes were observed during coring, but it was winter when the lake was frozen. Using a YSI ProDSS multiparameter water quality meter, surface water $\mathrm{pH}$ was measured at $6.84 \mathrm{pH}$ units.

\section{Methods}

\subsection{Coring, age model, and total organic carbon}

A $135 \mathrm{~cm}$ sediment core (YHC15A) was collected in $2015 \mathrm{CE}$ using a $6 \mathrm{~cm}$ diameter piston corer from the central region of Yuhuang Chi lake. The highly humified lake sediments contained no sizable macrofossils for radiocarbon analyses. Radiocarbon dating was instead carried out on five bulk organic sediment samples using accelerator mass spectrometry (AMS) at Beta Analytic, USA. There is a radiocarbon reservoir effect evident in the data (likely from old soil carbon input from the catchment), so we used a quadratic extrapolation to determine reservoir ages (Hou 

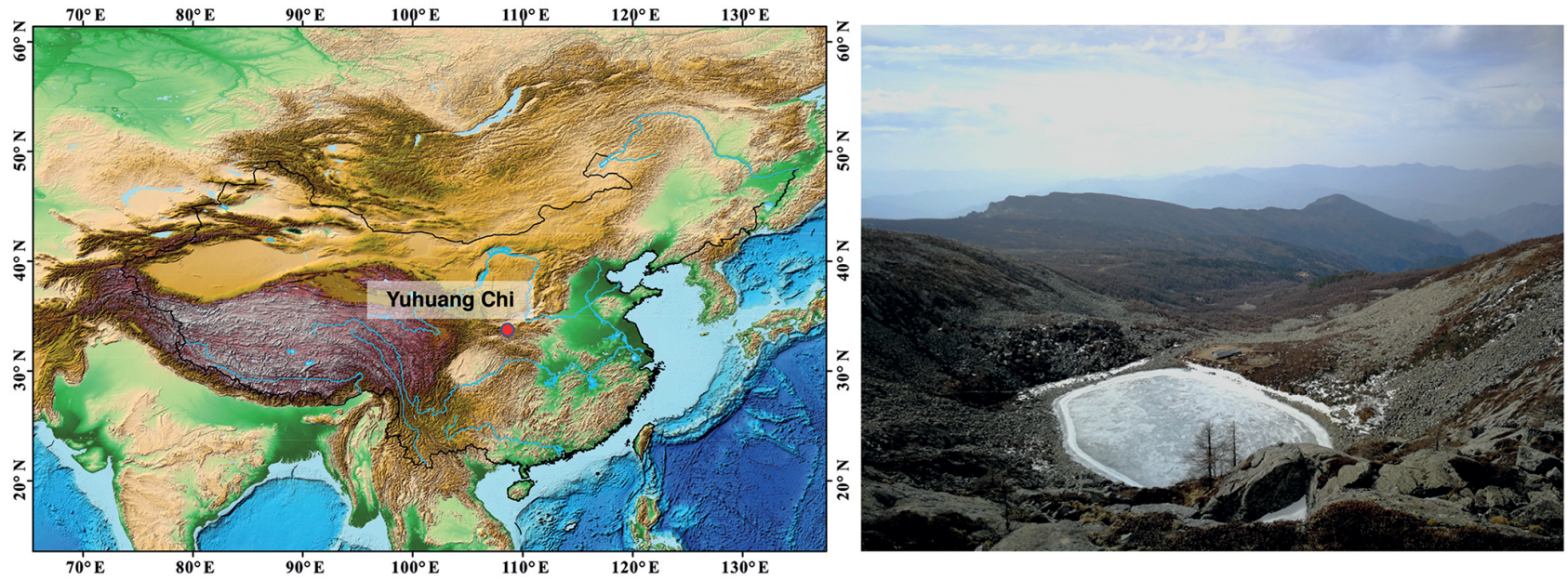

Figure 1. Regional position of Yuhuang Chi lake in the Qinling mountains of central Asia. The lake is situated $3370 \mathrm{~m}$ a.s.1., and it was formed by glacial activity. The photograph of the frozen lake to the right shows the small catchment and tundra vegetation.

et al., 2012). All the radiocarbon dates were fitted with a quadratic function $\left({ }^{14} \mathrm{Cage}=0.0693 \mathrm{depth}^{2}+17.31\right.$ depth + $\left.1340 ; R^{2}=0.9994\right)$, so we determined the top $(0 \mathrm{~cm})$ with a 1340-year reservoir age effect. An age-depth model was developed with smooth fit using CLAM 2.2 (Blaauw, 2010) in R, using the Intcal13 (Reimer et al., 2013) calibration curve. Total organic carbon (TOC) provides an estimate of the amount of organic carbon that escapes remineralisation before being incorporated into lake sediments. TOC was measured on contiguous $1 \mathrm{~cm}$ samples using an elemental analyser (Flash EA 1112).

\subsection{Diatoms}

Diatom analysis was performed on alternate $1 \mathrm{~cm}$ thick sediment samples. Approximately $0.1 \mathrm{~g}$ of wet sediment from each sample was prepared using standard procedures outlined in Battarbee et al. (2001). Organic matter was removed by heating each sample in $30 \% \mathrm{H}_{2} \mathrm{O}_{2}$ before $10 \%$ $\mathrm{HCl}$ was added to remove carbonates and any excess $\mathrm{H}_{2} \mathrm{O}_{2}$. Diatom concentrations were calculated through the addition of divinylbenzene (DVB) microspheres (concentration $8.02 \times 10^{5}$ spheres $\mathrm{cm}^{-3}$ ) to diatom suspensions, and diatom fluxes were calculated using sediment accumulation rates. Diatom suspensions were diluted and then pipetted onto coverslips to dry before being fixed onto microscope slides with Naphrax ${ }^{\circledR}$. Using a Zeiss Axiostar Plus ${ }^{\circledR}$ light microscope, diatoms were counted at $1000 \times$ magnification under an oilimmersion objective and phase contrast. A minimum of 300 diatom valves (min 331, max 591) were counted for each of the 67 samples. Diatoms were identified using a variety of flora including Krammer and Lange-Bertalot (1986, 1988, 1991a, b), Williams and Round (1987), and Lange-Bertalot (2001).
Diatom species were categorised according to ecological guilds commonly associated with the abundance of available resources (e.g. light, nutrients) and disturbance (e.g. grazing and turbulence) (after Passy, 2007; Rimet and Bouchez, 2012). The low-profile guild includes diatoms which attach themselves to substrates in erect, prostrate, and adnate forms, are very slow moving (Passy, 2007), and are generally adapted to low nutrient levels. High-profile guild diatoms are those of tall stature (e.g. they are filamentous, chain-forming, or found in mucilage tubes), and they are generally adapted to high levels of nutrients and low levels of disturbance (Passy, 2007). Motile diatoms are relatively fast-moving species that are tolerant of high levels of nutrients (Passy, 2007) and siltation processes (Battegazzore et al., 2004). A new planktic guild was determined by Rimet and Bouchez (2012), which includes centric species able to resist sedimentation in lake ecosystems.

\subsection{Multivariate analyses}

The magnitude of diatom turnover was initially estimated using detrended correspondence analysis (DCA), with square root transformation of the species data to stabilise variance and rare species being weighted lower. The axis 1 gradient length was 1.44 standard deviation units, so diatom abundances were reanalysed using principal components analysis (PCA). A log-linear contrast PCA was undertaken (appropriate for closed, relative abundance data; Lotter and Birks, 1993), with symmetric scaling of ordination scores so that scaling of both samples and species were optimised. Species compositional turnover was estimated using detrended canonical correspondence analysis (DCCA), with the diatom data constrained using dates from the calibrated age model (Smol et al., 2005). We used DCCA to estimate compositional turnover because sample scores are 

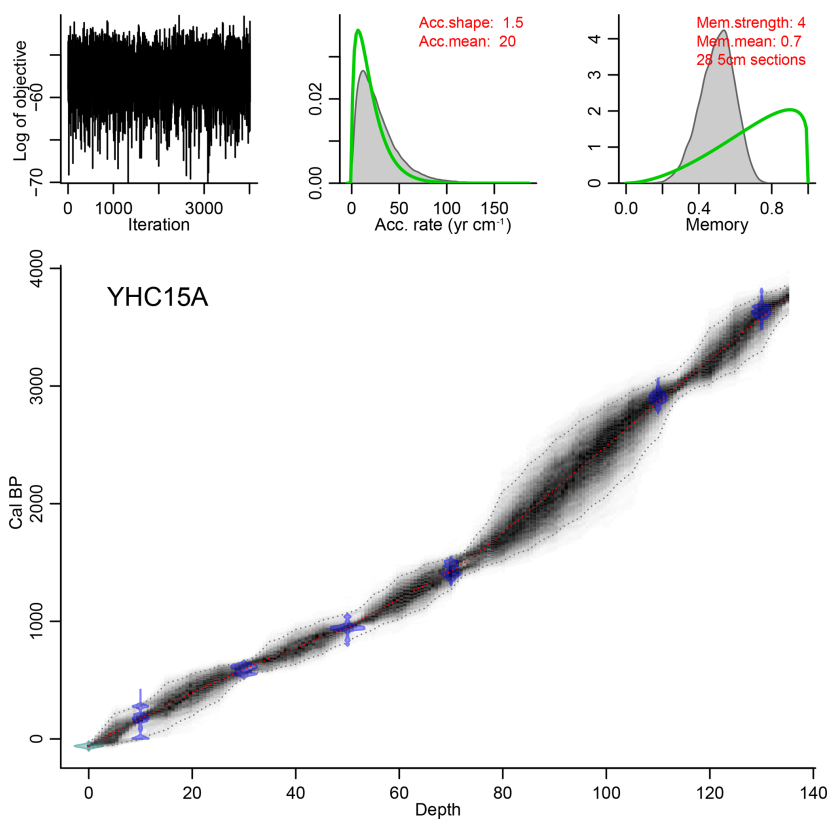

Figure 2. The age model determined on five radiocarbon dates of organic bulk sediments from core YHC15A. The age-depth model was developed with a smooth fitting using CLAM 2.2 (Blaauw, 2010).

scaled to be standard units through the process of detrending by segments and non-linear rescaling (Birks, 2007). Sample scores can therefore be interpreted as the amount of species turnover through time, making them ecologically useful and ideal for estimating compositional turnover. Ordinations were undertaken using Canoco5 (Šmilauer and Lepš, 2014). Breakpoint analysis, a form of segmented regression analysis, was used to determine major points of change in diatom guilds and turnover, using the segmented package in R v. 3.5.1 (Muggeo, 2008). Stringent $p$ values were adopted $(p<0.001)$ when determining any major changes observed. All stratigraphical profiles shown were constructed using C2 Data Analysis Version 1.7.7 (Juggins, 2014), and zones are determined using stratigraphical constrained cluster analysis by incremental sum of squares (CONISS) and broken stick analysis using the rioja package in R v. 3.5.1 (Juggins, 2017).

\section{Results}

\subsection{Core description and age model}

The lithology of the $135 \mathrm{~cm}$ long YHC15A core consisted entirely of grey-brown highly humified gyttja. Radiocarbon dates of TOC are given in Table 1, and an age-depth model determined using CLAM 2.2 (Blaauw, 2010) (shown in Fig. 2). Sediment rates are lower during the early part of the record, before ca. $1400 \mathrm{calBP}\left(0.28 \mathrm{~mm} \mathrm{yr}^{-1}\right)$, compared to sediments deposited during the past 1400 years $\left(0.48 \mathrm{~mm} \mathrm{yr}^{-1}\right)$.

\subsection{Diatoms}

A total of 170 species of diatom were identified from Yuhuang Chi lake, with the majority (120 species) being only of low occurrence ( $<1 \%$ in one or more samples). For much of the stratigraphy, diatoms were dominated by fragilarioids and naviculoids up to ca. $930 \mathrm{cal} \mathrm{BP},(1020 \mathrm{CE})$ after which they decline to be replaced by Monoraphidand Gomphonema-type taxa alongside the centric Lindavia. Stratigraphically constrained cluster analysis by incremental sum of squares analysis (CONISS) on diatom-relative abundance data reveals three zones: zone 1 (ca. 3550$2300 \mathrm{calBP}$ ), zone 2 (ca. $2300-615 \mathrm{calBP}$ ), and zone 3 (ca. 615 cal BP-present) (Figs. 3, 4). Zone 1 is dominated by diatoms in the high-profile guild (Fig. 4), notably fragilarioids Stauroforma exiguiformis and Staurosirella pinnata. Diatoms in the motile guild are well represented by the naviculoid Humidophila schmassmannii, together with Diadesmis gallica, Mayamaea atomus, and Mayamaea fossalis. The decline in S. exiguiformis at the top of the zone is accompanied by an increase in Pseudostaurosira brevistriata and a decline in motile diatoms, e.g. M. atomus. In zone 1, there is a gradual decline in compositional turnover and PCA1 sample scores. Zone 2 is marked by a notable increase in the planktic Lindavia bodanica and increasing P. brevistriata and Pseudostaurosira pseudoconstruens. Diversity in zone 2 exhibits a rather stable flora, dominated by $P$. brevistriata, $P$. pseudoconstruens, and L. bodanica, while Gomphonema olivaceoides and Karayevia suchlandtii appear in the record for the first time at ca. 1400 and $1070 \mathrm{cal} \mathrm{BP}$, respectively. Motile diatoms become persistently lower than the mean at this time during zone 2 , while low-profile diatom abundances increase to fluctuate about the average (Fig. 4). Zone 3 occurs just before a major change in diatom turnover (Fig. 3). Several species decline from the record altogether including $S$. exiguiformis and $H$. schmassmannii, while other species reach peak abundance for the whole profile, including L. bodanica, G. olivaceoides, and diatoms which occupy the low-profile guild status in general (Fig. 4). Denticula subtilis appears in the record for the first time at ca. $400 \mathrm{cal}$ BP $(1550 \mathrm{CE})$. During zone 3, low-profile and planktic diatoms increase to their highest values for the whole record, while high-profile and motile diatoms are persistently lower than the mean. Diatom fluxes range from $0.07 \times 10^{6}$ to $7.02 \times 10^{6}$ valves $\mathrm{cm}^{-2} \mathrm{yr}^{-1}$ (mean of $1.85 \times 10^{6}$ valves $\mathrm{cm}^{-2} \mathrm{yr}^{-1}$ ). When centred around the mean, fluxes are highest in zone 2, between ca. 1500 and $800 \mathrm{cal} \mathrm{BP}(450-1150 \mathrm{CE})$, but decline at ca. $800 \mathrm{cal} \mathrm{BP}$ $(1150 \mathrm{CE})$ to lowest values from ca. $600 \mathrm{cal} \mathrm{BP}(1350 \mathrm{CE})$ to the present (Fig. 3). The \% TOC values are low and range from $2.6 \%-4.3 \%$ (mean $3.45 \%$ ). TOC values were highest in zone 1 , declined in zone 2 , and reached lowest values, coincident with lowest values for compositional turnover, at ca. 1645 CE.

PCA highlights a very strong first axis gradient which accounts for over $45 \%$ of variation in the diatom data. 
Table 1. AMS $-{ }^{14} \mathrm{C}$ radiocarbon dates from Yuhuang Chi lake (core YHC15A).

\begin{tabular}{lrlrrrr}
\hline $\begin{array}{l}\text { Lab } \\
\text { no. }\end{array}$ & $\begin{array}{r}\text { Depth } \\
(\mathrm{cm})\end{array}$ & Material & $\begin{array}{r}\delta^{13} \mathrm{C} \\
(\% \circ \mathrm{VPDB})\end{array}$ & $\begin{array}{r}{ }^{14} \mathrm{C} \text { date } \pm \text { error } \\
(\mathrm{BP})\end{array}$ & $\begin{array}{r}{ }^{14} \mathrm{C} \text { date minus 1340 } \\
\text { reservoir age (BP) }\end{array}$ & $\begin{array}{r}\text { Weighted calibrated age } \\
\text { (no error) (cal BP) }\end{array}$ \\
\hline Beta-425231 & 10 & Bulk organic & -24.6 & $1530 \pm 30$ & $190 \pm 30$ & 168 \\
Beta-425232 & 30 & Bulk organic & -24.7 & $1920 \pm 30$ & $580 \pm 30$ & 595 \\
Beta-425233 & 50 & Bulk organic & -24.9 & $2370 \pm 30$ & $1030 \pm 30$ & 949 \\
Beta-417757 & 70 & Bulk organic & -24.8 & $2870 \pm 30$ & $1530 \pm 30$ & 1423 \\
Beta-425234 & 110 & Bulk organic & -24.8 & $4140 \pm 30$ & $2800 \pm 30$ & 2868 \\
Beta-417758 & 130 & Bulk organic & -24.9 & $4730 \pm 30$ & $3390 \pm 30$ & 3584 \\
\hline
\end{tabular}

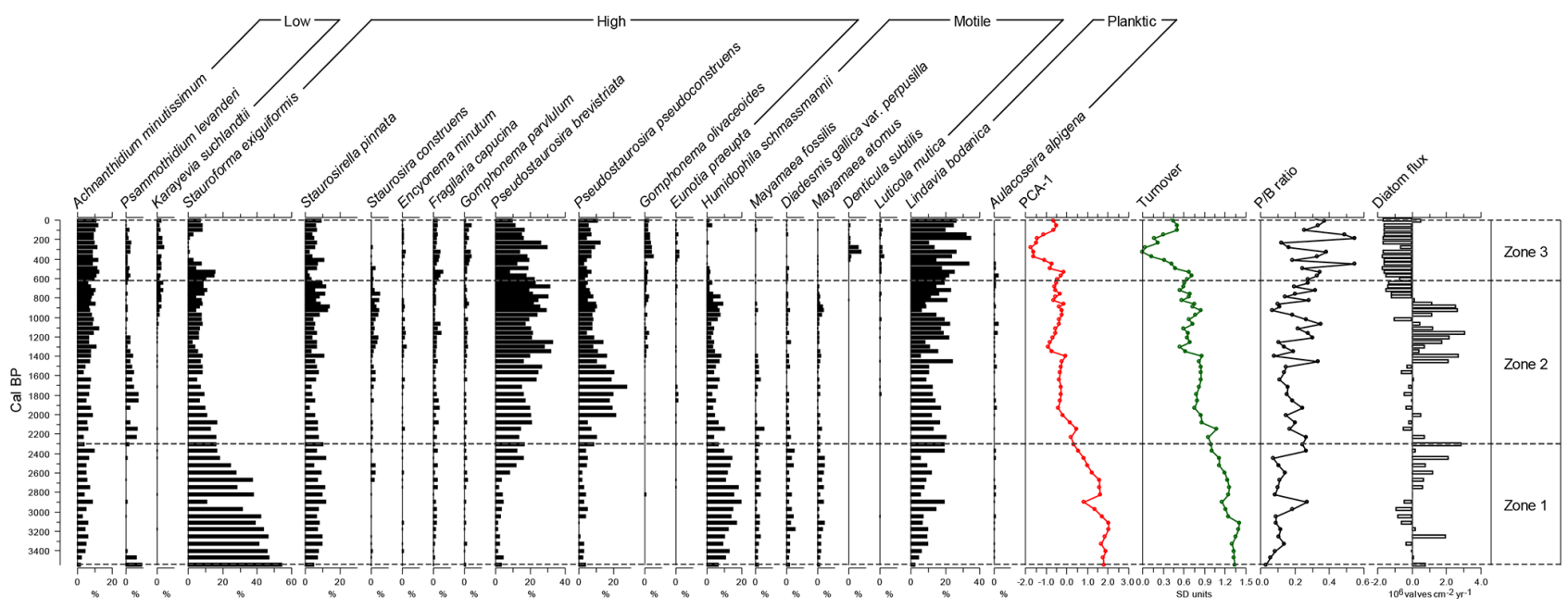

Figure 3. Diatoms shown greater than $3 \%$ in more than one sample. Diatom species are given as relative abundances. Also shown are PCA axis-1 scores for species and genera, compositional turnover values, planktonic-to-benthic $(\mathrm{P} / \mathrm{B})$ ratio data, and mean-centred diatom fluxes. Zones were delimited using CONISS - see text for details.

Trends in PCA-1 are most clearly seen in Fig. 5, as deviations around the mean. Breakpoint analysis indicates a major $(p<0.001)$ change in PCA axis 1 scores (Table 2$)$, close to the transition when PCA values switch from being higher than the mean to being lower than the mean, and low values persist for the rest of the record. Diatom compositional turnover (estimated from DCCA; $1.033 \mathrm{SD}$ units) shows a similar pattern to PCA-1, with breakpoints identified at ca. $515 \mathrm{calBP} \pm 40$ years (ca. 1435CE) and 335 cal BP \pm 33 years (ca. 1615 CE) (Table 2; Fig. 5).

\section{Discussion}

\subsection{Diatom assemblage change}

Sedimentary diatom assemblages in Yuhuang Chi lake are dominated by species in the Fragilariaceae (Fig. 3) from 3500 to 615 cal BP. Fragilarioids are often opportunistic, dominating assemblages in alpine and arctic lakes with a short growing season and long periods of ice cover (Lotter and Bigler, 2000). For example, July air temperature and ice cover duration have both been shown to have a significant influence on the abundance of fragilarioids in the European Alps (Schmidt et al., 2004), while in a subalpine lake in the Eastern Sayan Mountains (Russia), insolation and Northern Hemisphere air temperatures played a strong role on modulating fragilarioid responses through the Holocene (Mackay et al., 2012). The early part of our record is dominated by Stauroforma exiguiformis, a species common in dystrophic lakes (Flower et al., 1996). Its high abundance may be related to relatively high carbon sequestration during the very early part of the record in zone 1 (Fig. 5c). The decline in S. exiguiformis is concomitant with the increase in Humidophila schmassmannii and may be indicative of Yuhuang Chi lake becoming less dystrophic (Buczkó et al., 2015), which is perhaps linked to a progressively cooler (Stebich et al., 2015) and more arid (F. Chen et al., 2015) climate (Fig. 6), leading to increasingly frozen soils, and reducing the supply of allochthonous carbon. The decline in H. schmassmannii after ca. $2800 \mathrm{cal} \mathrm{BP}$ further tracks the switch to a progressively cooler and more arid climate (Wang et al., 2005; J. Chen et al., 2015).

Growth of the planktic diatom L. bodanica in oligotrophic lakes is related to increased mixing depth (Saros and Anderson, 2015), because it can tolerate relatively low light 


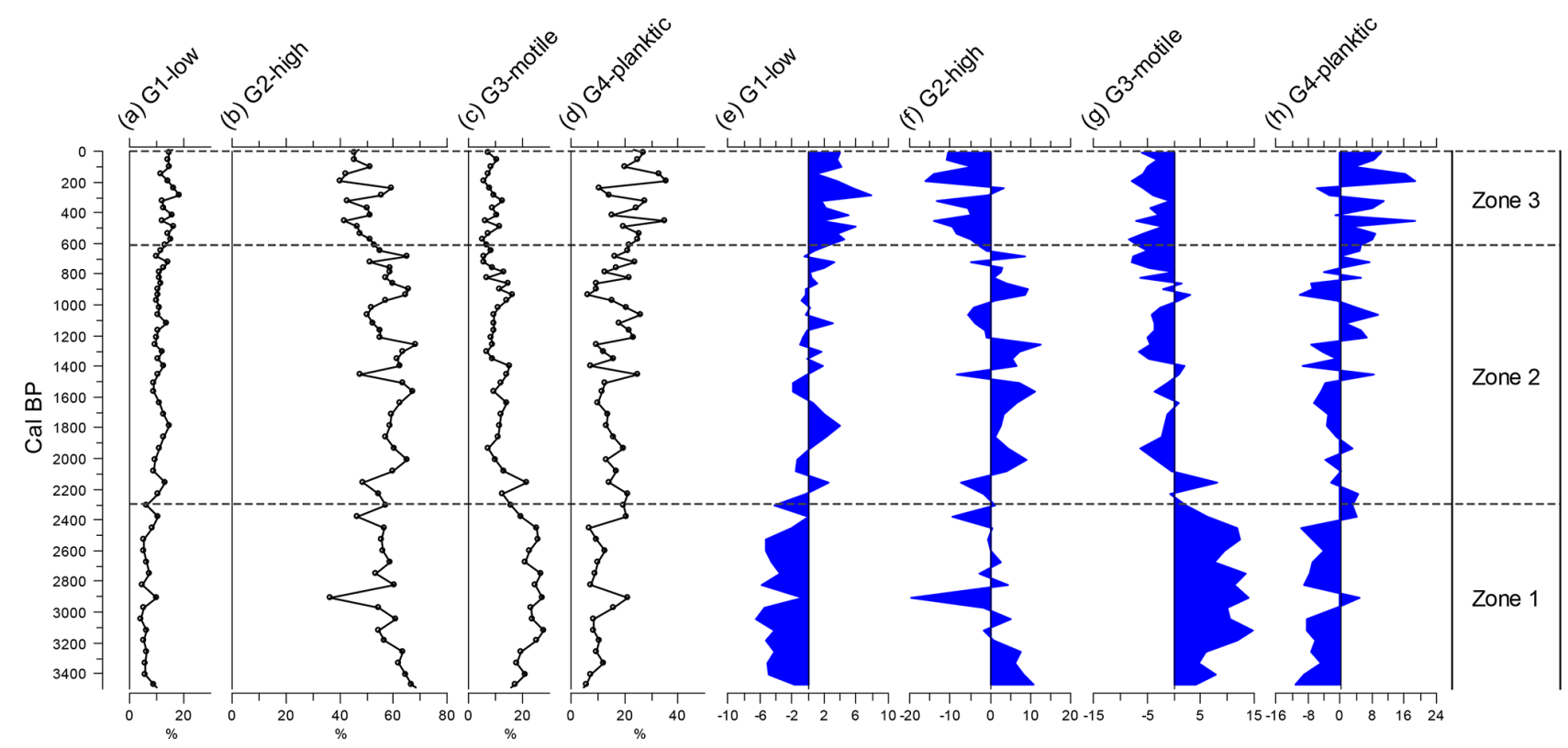

Figure 4. All diatoms were classified into one of four guilds (after Passy, 2007, and Rimet and Bouchez, 2012): low profile (guild 1), high profile (guild 2), motile (guild 3), and planktic (guild 4). Guilds are presented as relative abundances (\%) to the left and deviations around the mean to the right.

Table 2. Significant breakpoints in diatom trend data $(p<0.001)$.

\begin{tabular}{lrlll}
\hline & $\begin{array}{r}\text { Breakpoint 1 } \\
\text { (cal BP) }\end{array}$ & $p$ value & $\begin{array}{l}\text { Breakpoint 2 } \\
\text { (cal BP) }\end{array}$ & $p$ value \\
\hline Species PCA & $1850 \pm 200$ & $p<0.001$ & none & \\
Compositional turnover & $515 \pm 97$ & $p<0.001$ & $335 \mathrm{BP} \pm 33$ & $p<0.001$ \\
Guild 2 - high profile & $2910 \pm 127$ & $p<0.001$ & $1565 \mathrm{BP} \pm 175$ & $p<0.001$ \\
Guild 3 - motile & $2880 \pm 69$ & $p<0.001$ & $1960 \mathrm{BP} \pm 128$ & $p<0.001$ \\
\hline
\end{tabular}

levels and take advantage of increased nutrient availability (Malik and Saros, 2016). Therefore, as the neoglacial progressed, mixing of the lake may have increased gradually, allowing this taxon to eventually dominate for most of the past 615 years, even though diatom fluxes (Fig. 3) and \% TOC (Fig. 5) were relatively low, which is indicative of overall low diatom productivity.

\subsection{Diatom traits}

Even though we do not have quantitative estimates of nutrients in this remote lake, we can start to make inferences about nutrient availability from the traits exhibited by the diatom communities themselves. For example, fragilarioids identified at Yuhuang Chi lake can be classified as high-profile diatoms (i.e. of tall stature), i.e. able to compete effectively for resources such as nutrients and light. However, their tall stature also makes them susceptible to disturbance (Passy, 2007), including turbulence in alpine lakes with short waterresidency times (Rimet et al., 2019). Their dominance at Yuhuang Chi lake from 3500 to 615 cal BP suggests that nu- trients and light were not limiting (Passy and Larson, 2019) for much of the sequence. Herbivory was likely low as well (Passy and Larson, 2019), because high-profile diatoms are not well adapted to high grazing pressures, which are generally low in alpine lakes (Rimet et al., 2019).

The decline in high-profile guild values with a concomitant increase in low-profile and planktic guilds since $615 \mathrm{cal} \mathrm{BP}$ suggests that environmental conditions in Yuhuang Chi lake changed. Diatoms belonging to the lowprofile guild attach themselves to substrates in erect, prostrate, and adnate forms (Passy, 2007), which means that although they are able to tolerate relatively high disturbance, they also need to withstand an increase in the number of resources that becomes limiting to them; i.e. they are well adapted to low nutrient concentrations (Berthon et al., 2011). The planktic guild was proposed by Rimet and Bouchez (2012) alongside the high, low, and motile guilds determined by Passy (2007), as diatoms are able to resist sedimentation through the water column and, in our lake, this guild is dominated by $L$. bodanica. The fact that $L$. bodanica 


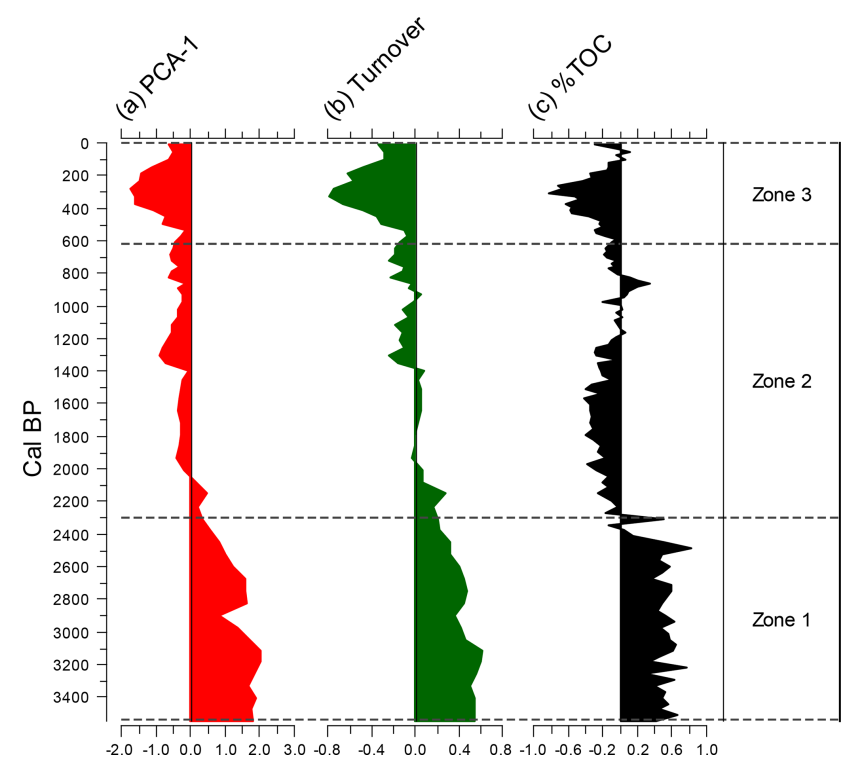

Figure 5. Ordination, compositional turnover, and TOC trends shown as deviations around the mean.

can tolerate low light conditions, and through turbulence of the water column obtain the nutrients that it needs to grow, is again indicative of resources, such as nutrients, becoming more limiting since the middle of the 14 th century.

\subsection{Diatom compositional turnover}

In aquatic environments, when disturbance increases or the number of limiting resources increases, such as a decline in nutrient and/or light availability, deterministic processes become more important than stochastic ones in structuring aquatic communities (Chase, 2010). Increasing deterministic processes leads to a decline in compositional turnover because disturbance or stress can act as environmental filters (Larson et al., 2016) through niche selection. The decline in turnover between 3100 and $1900 \mathrm{cal} \mathrm{BP}$ is gradual, and it reflects the slow long-term change in low-profile guild diatoms increasing and motile guild diatoms declining. An increase in low-profile diatoms hints at increasing disturbance and/or declining nutrients (Passy, 2007), while a decline in motile diatoms may be indicative of a decline in siltation processes within the lake (Battegazzore et al., 2004). Over this time period our data also show a marked decline in TOC sequestration to the bottom sediments (Fig. 5c). We suggest therefore that the diatom and TOC data both point to a reduction in dissolved organic carbon in Yuhuang Chi lake concurrent with cooling regional temperatures and increased aridity (F. Chen et al., 2015).

There are also periods when compositional turnover stabilised or even increased slightly during the neoglacial, e.g. between ca. 1900 and $1400 \mathrm{calBP}$ (Fig. 6a). This period coincides with distinctly warmer Arctic and European temperatures (PAGES 2k Consortium, 2013), commonly referred to as the "Roman Warm Period". Precipitation in central China is closely tied to the intensity of the Asian summer monsoon (ASM) (F. Chen et al., 2015), and at this time the summer monsoon was rather stable (Fig. 6d). Diatoms were dominated by high-profile species, indicating that nutrients were not in limited supply, perhaps being washed in from the catchment with summer monsoon rains.

Between 1400 and $615 \mathrm{calBP}$ (550-1335 CE), turnover, although lower than average (Fig. 6a), did not decline (Fig. 3), indicating an increased competition between species (Larson et al., 2016). This period coincides with the Medieval Climatic Anomaly (MCA), sometimes referred to as the Medieval Warm Period. Sub-decadal isotopic records from a stalagmite from a Buddha cave in the Qinling mountains indicate a period of a warm, wet climate between ca. 985 and 475 cal BP (965-1475 CE) (Paulsen et al., 2003), while phenological records, including the beginning of tree flowering along the Yellow and Yangtze rivers, show that winter halfyear temperatures were high between 1380-640 cal BP (5701310 CE) (Ge et al., 2003). An increased presence of Quercus and Betula pollen on Mount Taibai also suggest warm, wet conditions ( $\mathrm{Li}$ et al., 2005; Wang et al., 2016) with temperatures perhaps being as much as $2^{\circ} \mathrm{C}$ warmer than mean annual temperatures observed today ( $\mathrm{Li}$ et al., 2005). These local climate indicators tie in well with regional monsoon patterns; monsoon strength was higher in central (Paulsen et al., 2003; J. Chen et al., 2015; Wang et al., 2016) and northeast China (F. Chen et al., 2015; J. Chen et al., 2015) than north-west China (J. Chen et al., 2015), while, globally, lowlatitude temperatures increased (Fig. 6d).

\subsection{Abrupt ecological change during centennial-scale cold events}

Against a backdrop of low Northern Hemisphere summer insolation (Fig. 6g), amplified by centennial-scale oceanic variability (Renssen et al., 2006), late Holocene cold events were caused by several "overlapping" factors (such as volcanic eruptions and solar minima) (Wanner et al., 2014). The most recent wide-scale cold event is the period commonly known as the Little Ice Age approximately 1300-1850 CE, caused by several interacting time-transgressive forcings, including reduced solar activity during the late 17th century (Shindell et al., 2001), increased volcanic activity during the early 19th century (Brönnimann et al., 2019), and overall reduced Gulf Stream flow (Lund et al., 2006). It is the cooling event that we focus on in this study, because cluster analyses of diatom assemblages delineate the boundary between zones 2 and 3 at $615 \mathrm{cal} \mathrm{BP}(1335 \mathrm{CE})$, and there are two significant breakpoints in compositional turnover including when turnover is at its lowest in the whole record at ca. 335-330 cal BP (16151620 CE) (Table 2).

Describing the Little Ice Age as a period characterised by cooler climate and glacier readvance is rather simplis- 


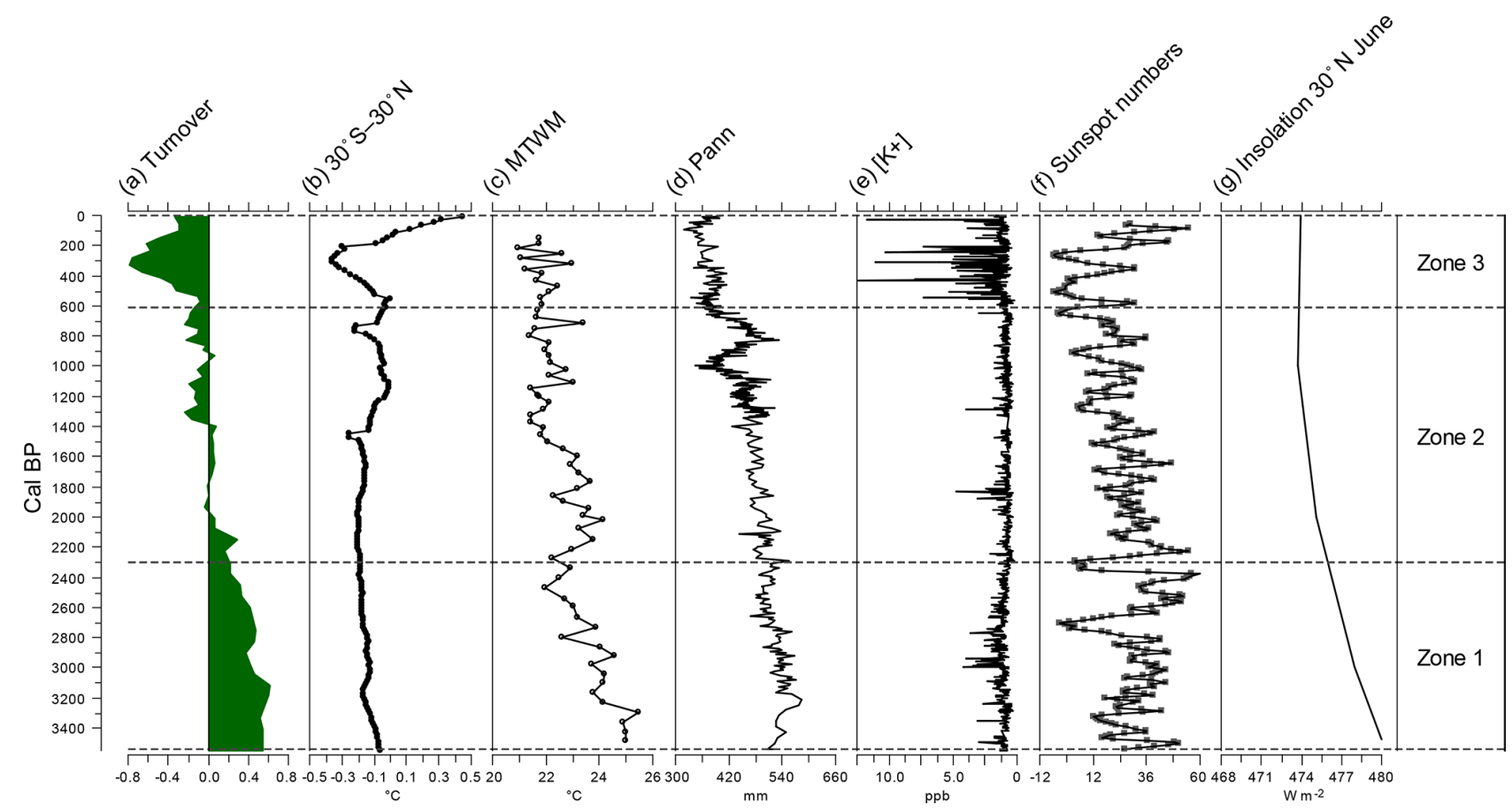

Figure 6. Compositional turnover (deviations around the mean) plotted alongside internal and external climate forcings: mean temperature stack records for low-latitude temperature anomalies (panel b; Marcott et al., 2013); NE China pollen-inferred mean temperature warmest month (MTWM) (July) (panel c; Stebich et al., 2015); trends in pollen-inferred mean annual precipitation (panel d; F. Chen et al., 2015); K ${ }^{+}$ concentrations in the GISP (Greenland Ice Sheet Project) ice core (panel e; Mayewski et al., 2004); sunspot numbers (panel f; Solanki et al., 2004); June solar insolation at $30 \mathrm{~N}\left(\mathrm{~W} \mathrm{~m}^{-2}\right)$ (panel $\mathbf{g}$; Berger and Loutre, 1991).

tic, but one that has proven quite resilient, even as its complexities are better understood (e.g. Matthews and Briffa, 2005). As more regions are investigated, impacts extend to changes in aridity as well as temperature. For example, J. Chen et al. (2015) demonstrated that, by and large, regions north of $34^{\circ}$ latitude (where our study site is located) were generally drier than regions further south, with the extent of aridity being affected by ocean-atmosphere interactions, such as ENSO (El Niño-Southern Oscillation) and its teleconnections to SE Asia. The LIA is especially characterised by a strengthened Siberian High (SH), a semipermanent anticyclone centred over Eurasia which strengthens intensively every winter. A strong Siberian High results in a strong East Asian winter monsoon (EAWM) (Zhang et al., 1997). $\mathrm{K}^{+}$concentrations in the GISP (Greenland Ice Sheet Project) ice core clearly show that the Siberian High was especially strong between ca. 550 and 150 calBP (1400-1800 CE) (Fig. 6f), assuming that potassium is likely sourced from central Asian dust via long-range transport to the Greenland ice sheet (Meeker and Mayewski, 2002). Concurrent with increased aridity, global low-latitude temperature records show rapid cooling at this time (Fig. 6b; Marcott et al., 2013), which in China led to very low winter anomalies (Ge et al., 2003) and lowest summer pollen-inferred temperatures in NE China (Fig. 6c).
Very low diatom fluxes characterise the past 800 years at Yuhuang Chi lake (Fig. 3), which is indicative of reduced diatom productivity that is coincident with a prevailing colder climate. Lowest compositional turnover at ca. 335330 cal BP (1615-1620 CE), linked to the disappearance of S. exiguiformis, may be due to enhanced frozen soils, leading to reduced carbon transport to the lake, while the disappearance of $H$. schmassmannii may be because it cannot tolerate such low water temperatures (Buczkó et al., 2015), alongside other factors such as a decline in siltation (Battegazzore et al., 2004). Denticula subtilis is a very motile diatom, and in the Canadian high Arctic it is characteristic of shallow lakes with elevated conductivity (Antoniades et al., 2005). It may therefore be reflective of the lake becoming more shallow due to increased aridity. Elsewhere, precipitation minima were reconstructed from nearby by Gonghai Lake (F. Chen et al., 2015a) and at the neighbouring Sanqing Chi lake; high Larix and Ephedra pollen frequencies are interpreted as being indicative of cold, dry conditions (Wang et al., 2016). The fact that minimum turnover and highest values for low-profile diatoms are observed at this time indicates nutrient limitation and/or significant disturbance, which has led to specialised diatoms to occupy niches where competition was very low (Larson et al., 2016). Following harshest conditions for diatom growth in Yuhuang Chi lake during the early 17th cen- 
tury, turnover increases once more, which is indicative of increased competition among species (Larson et al., 2016).

While a cold and arid climate during the LIA had a major impact on diatom diversity in Yuhuang Chi lake, impacts from previous centennial-scale cold events, such as the $2800 \mathrm{BP}$ event, are less conclusive. Like the LIA, the event dated at ca. $2800 \mathrm{BP}$ is concurrent with a deep, abrupt reduction in solar activity (Fig. 6f), which led to a decline in surface water temperatures in the North Atlantic (Andersson et al., 2003), weaker meridional overturning circulation (Hall et al., 2004), and sea-ice expansion (Renssen et al., 2006). But although these events led to a rapid weakening in ASM intensity in southern China (Wang et al., 2005), reconstructed precipitation from Gonghai Lake in northern China suggests that aridity was already increasing from ca. $3100 \mathrm{cal}$ BP (Fig. 6d) (J. Chen et al., 2015). There is a small increase in GISP2 $\mathrm{K}^{+}$ concentrations, which suggests that the Siberian High during the time of the $2800 \mathrm{BP}$ event did not reach the strengths observed during the LIA (Fig. 6e), but still led to regional summertime cooling (Fig. 6c, Stebich et al., 2015). At Yuhuang Chi lake, these changes in climate may have caused the small, temporary decline in both compositional turnover and total diatom flux but also a significant decline in high-profile diatoms that is concomitant with an increase in L. bodanica. This may suggest increased water column instability and turbulence in the lake (Saros and Anderson, 2015).

\section{Conclusions}

Diatom turnover in the Qinling mountains of central China demonstrates strong directional change. The decline in turnover over the past 3500 years mirrors declining lowlatitude June insolation, which drives overall low-latitude cooling (Marcott et al., 2013). This suggests a strong link between orbitally forced climate change and increasingly deterministic processes affecting aquatic ecosystems in this highaltitude region of central China. Over the last 1300 years, impacts related to the Medieval Climatic Anomaly and the Little Ice Age are also expressed in the palaeolimnological records from Yuhuang Chi lake. Increased diatom fluxes (Fig. 3) are coincident with increased regional summer precipitation during the MCA (F. Chen et al., 2015). Colder, more arid conditions during the Little Ice Age, linked to a very strong Siberian High, led to lowest diatom turnover and carbon sequestration for the past 3500 years, possibly due to the lake becoming more shallow at this time. Our study highlights the value of interpreting diatom changes through compositional turnover and ecological trait analyses of their growth forms.

Data availability. Diatom and radiocarbon data have been deposited with the NOAA World Data Service for Paleoclimatology (https://www.ncdc.noaa.gov/paleo/study/29232; Cheng et al., 2020).
Author contributions. BC, JC, and $\mathrm{QZ}$ designed the study. $\mathrm{BC}$ undertook the diatom analyses and $\mathrm{AZ}$ the radiocarbon dating. JA provided assistance with statistical analyses, and AWM prepared the article with contributions from all authors.

Competing interests. The authors declare that they have no conflict of interest.

Acknowledgements. We would like to thank the Chinese Scholarship Council for allowing Bo Cheng to visit UCL and three anonymous referees for their insightful comments.

Financial support. This research has been supported by a China Scholarship Council award to Bo Cheng and by the National Natural Science Foundation of China (grant nos. 41771208 and 41790421).

Review statement. This paper was edited by Keely Mills and reviewed by three anonymous referees.

\section{References}

Andersson, C., Risebrobakken, B., Jansen, E., and Dahl, S. O.: Late Holocene surface ocean conditions of the Norwegian Sea (Vøring Plateau), Paleoceanography, 18, 1044, https://doi.org/10.1029/2001PA000654, 2003.

Anderson, M. J., Crist, T. O., Chase, J. M., Vellend, M., Inouye, B. D., Freestone, A. L., Sanders, N. J., Cornell, H. V., Comita, L. S., Davies, K. F. and Harrison, S. P.: Navigating the multiple meanings of $\beta$ diversity: a roadmap for the practicing ecologist, Ecol. Lett., 14, 19-28, 2011.

Antoniades, D., Douglas, M. S., and Smol, J. P.: Benthic diatom autecology and inference model development from the Canadian high arctic Archipelago 1, J. Phycol., 41, 30-45, 2005.

Battarbee, R. W., Jones, V. J., Flower, R. J., Cameron, N. G., Bennion, H., Carvalho, L., and Juggins, S.: Diatoms, in: Tracking Environmental Change Using Lake Sediments, edited by: Smol, J. P., Birks, H. J. B., and Last, W. M., Kluwer Academic Publishers, Dordrecht, pp. 155e201, 2001.

Battegazzore, M., Morisi, A., Gallino, B., and Fenoglio, S.: Environmental quality evaluation of Alpine springs in NW Italy using benthic diatoms, Diatom Res., 19, 149-165, 2004.

Berger, A. and Loutre, M. F.: Insolation values for the climate of the past 10 million years, Quaternary Sci. Rev., 10, 297-317, 1991.

Berthon, V., Bouchez, A., and Rimet, F.: Using diatom life-forms and ecological guilds to assess organic pollution and trophic level in rivers: a case study of rivers in south-eastern France, Hydrobiologia, 673, 259-271, 2011.

Birks, H. J. B.: Estimating the amount of compositional change in late-Quaternary pollen-stratigraphical data, Veg. Hist. Archaeobot., 16, 197-202, 2007.

Blaauw, M.: Methods and code for "classical" age-modelling of radiocarbon sequences, Quat. Geochron., 5, 512-518, 2010.

Brönnimann, S., Franke, J., Nussbaumer, S. U., Zumbühl, H. J., Steiner, D., Trachsel, M., Hegerl, G. C., Schurer, A., Worni, M., 
Malik, A., and Flückiger, J.: Last phase of the Little Ice Age forced by volcanic eruptions, Nat. Geosci., 12, 650-656, 2019.

Buczkó, K., Wojtal, A. Z., Beszteri, B., and Magyari, E. K.: Morphology and distribution of Navicula schmassmannii and its transfer to genus Humidophila, Studia Botanica Hungarica, 46, 25-41, 2015.

Buytaert, W., Moulds, S., Acosta, L., De Bievre, B., Olmos, C., Villacis, M., Tovar, C., and Verbist, K. M. J.: Glacial melt content of water use in the tropical Andes, Environ. Res. Lett., 12, 114014, https://doi.org/10.1088/1748-9326/aa926c, 2017.

Chase, J. M.: Drought mediates the importance of stochastic community assembly, P. Natl. Acad. Sci. USA, 104, 17430-17434, 2010.

Chen, F., Xu, Q., Chen, J., Birks, H. J. B., Liu, J., Zhang, S., Jin, L., An, C., Telford, R. J., Cao, X., and Wang, Z.: East Asian summer monsoon precipitation variability since the last deglaciation, Sci. Rep.-UK, 5, 11186, https://doi.org/10.1038/srep11186, 2015.

Chen, J., Chen, F., Feng, S., Huang, W., Liu, J., and Zhou, A.: Hydroclimatic changes in China and surroundings during the Medieval Climate Anomaly and Little Ice Age: spatial patterns and possible mechanisms, Quaternary Sci. Rev., 107, 98-111, 2015.

Cheng, B., Adams, J., Chen, J., Zhou, A. F., Zhang, Q., and Mackay, A. W.: Lake Yuhuang Chi, China 3,700 Year Diatom Data, available at: https://www.ncdc.noaa.gov/paleo/study/29232, last access: 17 March 2020.

Cook, E. R., Anchukaitis, K. J., Buckley, B. M., D’Arrigo, R. D., Jacoby, G. C., and Wright, W. E.: Asian monsoon failure and megadrought during the last millennium, Science, 328, 486-489, 2010.

Cook, E. R., Krusic, P. J., Anchukaitis, K. J., Buckley, B. M., Nakatsuka, T., Sano, M., and PAGES Asia2k Members: Tree-ring reconstructed summer temperature anomalies for temperate East Asia since 800 C.E., Clim. Dynam., 41, 2957-2972, 2013.

Fan, J. T., Li, J. S., Xia, R., Hu, L. L., Wu, X. P., and Guo, L.: Assessing the impact of climate change on the habitat distribution of the giant panda in the Qinling Mountains of China, Ecol. Model., 274, 12-20, 2014.

Felde, V. A., Flantua, S. G., Jenks, C. R., Benito, B. M., De Beaulieu, J. L., Kuneš, P., Magri, D., Nalepka, D., Risebrobakken, B., ter Brak, C. J., and Allen, J. R.: Compositional turnover and variation in Eemian pollen sequences in Europe, Veg. Hist. Archaeobot., 29, 101-109, https://doi.org/10.1007/s00334-019-00726-5, 2020.

Flower, R. J., Jones, V. J., and Round, F. E.: The distribution and classification of the problematic Fragilaria (virescens V.) exigua Grun./Fragilaria exiguiformis (Grun.) Lange-Bertalot: A new species or a new genus?, Diatom Res., 11, 41-57, 1996.

Ge, Q., Zheng, J., Fang, X., Man, Z., Zhang, Z., Zhang, P., and Wang, W.: Winter half-year temperature reconstruction for the middle and lower reaches of the Yellow River and Yangtze River, China, during the past 2000 years, Holocene, 13, 933-940, 2003.

Grêt-Regamey, A., Brunner, S. H., and Kienast, F.: Mountain ecosystem services: who cares?, Mt. Res. Dev., 32, S23-S34, 2012.

Guo, J., Huang, G., Wang, X., Li, Y., and Lin, Q.: Investigating future precipitation changes over China through a high-resolution regional climate model ensemble, Earth's Future, 5, 285-303, 2017.
Hall, I. R., Bianchi, G. G., and Evans, J. R.: Centennial to millennial scale Holocene climate-deep water linkage in the North Atlantic, Quaternary Sci. Rev., 23, 1529-1536, 2004.

Hou, J., D'Andrea, W. J. and Liu, Z.: The influence of ${ }^{14} \mathrm{C}$ reservoir age on interpretation of paleolimnological records from the Tibetan Plateau, Quaternary Sci. Rev., 48, 67-79, 2012.

Juggins, S.: C2 version 1.7.7: software for ecological and palaeoecological data, University of Newcastle, Newcastle, 2014.

Juggins, S.: rioja: Analysis of Quaternary Science Data, R package version 3.5.1, available at: http://cran.r-project.org/package= rioja (last access: 31 May 2019), 2017.

Korhonen, J. J., Soininen, J., and Hillebrand, H.: A quantitative analysis of temporal turnover in aquatic species assemblages across ecosystems, Ecology, 91, 508-517, 2010.

Krammer, K. and Lange-Bertalot, H.: Bacillariophyceae: Naviculaceae, in: Süsswasserflora von Mitteleuropa. Band 2, Teil 1, edited by: Ettl, H., Gerloff, J., Heynig, H., and Mollenhauer, D., Gustav Fischer, Stuttgart, 1986.

Krammer, K. and Lange-Bertalot, H.: Bacillariophyceae: Bacillariaceae, Epithemiaceae, Surirellaceae, in: Süsswasserflora von Mitteleuropa. Band 2, Teil 2, edited by: Ettl, H., Gerloff, J., Heynig, H., and Mollenhauer, D., Gustav Fischer, Stuttgart, 1988.

Krammer, K. and Lange-Bertalot, H.: Bacillariophyceae: Achnanthaceae, Kritische Ergänzungen zu Navicula (Lineolatae) und Gomphonema Gesamtliterarurverzeichnis, in: Süsswasserflora von Mitteleuropa. Band 2, Teil 4, edited by: Ettl, H., Gerloff, J., Heynig, H., and Mollenhauer, D., Gustav Fischer, Stuttgart, 1991a.

Krammer, K. and Lange-Bertalot, H.: Bacillariophyceae: Centrales, Fragilariaceae, Eunotiaceae, in: Süsswasserflora von Mitteleuropa. Band 2, Teil 3, edited by: Ettl, H., Gerloff, J., Heynig, H., and Mollenhauer, D., Gustav Fischer, Stuttgart, 1991b.

Lange-Bertalot, H.: Diatoms of Europe, Volume 2: Navicula sensu stricto. 10 genera separated from Navicula sensu lato Frustulia, in: Diatoms of Europe: diatoms of the European inland waters and comparable habitats, edited by: Lange-Bertalot, H., A.R.G. Gantner Verlag K.G., Ruggell, Germany, 2001.

Larson, C. A., Adumatioge, L., and Passy, S. I.: The number of limiting resources in the environment controls the temporal diversity patterns in the algal benthos, Microbial Ecol., 72, 64-69, 2016.

Leprieur, F., Tedesco, P. A., Hugueny, B., Beauchard, O., Dürr, H. H., Brosse, S., and Oberdorff, T.: Partitioning global patterns of freshwater fish beta diversity reveals contrasting signatures of past climate changes, Ecol. Lett., 14, 325-334, 2011.

Li, X., Dodson, J., Zhou, J., Wang, S., and Sun, Q.: Vegetation and climate variations at Taibai, Qinling Mountains in central China for the last 3500 cal BP, J. Integr. Plant Biol., 47, 905-916, 2005.

Liu, H., Tang, Z., Dai, J., Tang, Y., and Cui, H.: Larch timberline and its development in North China, Mt. Res. Dev., 22, 359-367, 2002.

Liu, J., Rühland, K. M., Chen, J., Xu, Y., Chen, S., Chen, Q., Huang, W., Xu, Q., Chen, F., and Smol, J. P.: Aerosol-weakened summer monsoons decrease lake fertilization on the Chinese Loess Plateau, Nat. Clim. Change, 7, 190-195, 2017.

Lotter, A. F. and Bigler, C.: Do diatoms in the Swiss Alps reflect the length of ice cover, Aquat. Sci., 62, 125-141, 2000. 
Lotter, A. F. and Birks, H. J. B.: The impact of the Laacher See tephra on terrestrial and aquatic ecosystems in the Black Forest, southern Germany, J. Quat. Sci., 8, 263-276, 1993.

Lund, D. C., Lynch-Stieglitz, J., and Curry, W. B.: Gulf Stream density structure and transport during the past millennium, Nature, 444, 601-604, 2006.

Mackay, A. W., Bezrukova, E. V., Leng, M. J., Meaney, M., Nunes, A., Piotrowska, N., Self, A., Shchetnikov, A., Shilland, E., Tarasov, P., Wang, L., and White, D.: Aquatic ecosystem responses to Holocene climate change and biome development in boreal, central Asia, Quaternary Sci. Rev., 41, 119-131, 2012.

Malik, H. I. and Saros, J. E.: Effects of temperature, light and nutrients on five Cyclotella sensu lato taxa assessed with in situ experiments in arctic lakes, J. Plankton Res., 38, 431-442, 2016.

Mann, M. E., Zhang, Z., Rutherford, S., Bradley, R. S., Hughes, M. K., Shindell, D., Ammann, C., and Faluvegi, G., and Ni, F.: Global signatures and dynamical origins of the Little Ice Age and Medieval Climate Anomaly, Science, 326, 1256-1260, 2009.

Marcott, S. A., Shakun, J. D., Clark, P. U., and Mix, A. C.: A reconstruction of regional and global temperature for the past 11,300 years, Science, 339, 1198-1201, 2013.

Matthews, J. A. and Briffa, K. R.: The "Little Ice Age": reevaluation of an evolving concept, Geogr. Ann. A., 87, 7-36, 2005.

Mayewski, P. A., Rohling, E. E., Stager, J. C., Karlén, W., Maasch, K. A., Meeker, L. D., Meyerson, E. A., Gasse, F., van Kreveld, S., Holmgren, K., Lee-Thorp, J., Rosqvist, G., Rack, F., Staubwasser, M., Schneider, R. R., and Steig, E. J.: Holocene climate variability, Quaternary Res., 62, 243-255, 2004.

Meeker, L. D. and Mayewski, P. A.: A 1400-year high-resolution record of atmospheric circulation over the North Atlantic and Asia, Holocene, 12, 257-266, 2002.

Messerli, B., Viviroli, D., and Weingartner, R.: Mountains of the world: vulnerable water towers for the 21 st century, Ambio, 13, 29-34, 2004.

Muggeo, V. M. R.: Segmented: An R Package to Fit Regression Models with Broken-Line Relationships, R News, 8, 20-25, 2008.

PAGES 2k Consortium: Continental-scale temperature variability during the past two millennia, Nat. Geosci., 6, 339e346, https://doi.org/10.1038/NGEO1797, 2013.

Passy, S. I.: Diatom ecological guilds display distinct and predictable behaviour along nutrient and disturbance gradients in running waters, Aquat. Bot., 86, 171-178, 2007.

Passy, S. I. and Larson, C. A.: Niche dimensionality and herbivory control stream algal biomass via shifts in guild composition, richness, and evenness, Ecology, 1-11, e02831, https://doi.org/10.1002/ecy.2831, 2019.

Paulsen, D. E., Li, H. C., and Ku, T. L.: Climate variability in central China over the last 1270 years revealed by high-resolution stalagmite records, Quaternary Sci. Rev., 22, 691-701, 2003.

Pepin, N., Bradley, R. S., Diaz, H. F., Baraër, M., Caceres, E. B., Forsythe, N., Fowler, H., Greenwood, G., Hashmi, M. Z., Liu, X. D., and Miller, J. R.: Elevation-dependent warming in mountain regions of the world, Nat. Clim. Change, 5, 424-430, 2015.

Reimer, P., Bard, E., Bayliss, A., Beck, J. W., Blackwell, P. G., Bronk Ramsey, C., Buck, C. E., Cheng, H., Edwards, R. L., Friedrich, M., Grootes, P. M., Guilderson, T. P., Haflidason, H., Hajdas, I., Hatté, C., Heaton, T. J., Hoffmann, D. L., Hogg, A. G.,
Hughen, K. A., Kaiser, K. F., Kromer, B., Manning, S. W., Niu, M., Reimer, R. W., Richards, D. A., Scott, E. M., Southon, J. R., Staff, R. A., Turney, C. S. M., and van der Plicht, J.: IntCal13 and Marine13 radiocarbon age calibration curves $0-50,000$ years cal BP, Radiocarbon, 55, 1869-1887, 2013.

Renssen, H., Goosse, H., and Muscheler, R.: Coupled climate model simulation of Holocene cooling events: oceanic feedback amplifies solar forcing, Clim. Past, 2, 79-90, https://doi.org/10.5194/cp-2-79-2006, 2006.

Rimet, F. and Bouchez, A.: Life-forms, cell-sizes and ecological guilds of diatoms in European rivers, Knowl. Manag. Aquat. Ecosyst., 406, 1-14, 2012.

Rimet, F., Feret, L., Bouchez, A., Dorioz, J.-M., and Dambrine, E.: Factors influencing the heterogeneity of benthic diatom communities along the shoreline of natural alpine lakes, Hydrobiologia, 839, 103-118, 2019.

Saros, J. E. and Anderson, N. J.: The ecology of the planktonic diatom Cyclotella and its implications for global environmental change studies, Biol. Rev., 90, 522-541, 2015.

Schmidt, R., Kamenik, C., Lange-Bertalot, H., and Klee, R.: Fragilaria and Staurosira (Bacillariophyceaea) from sediment surfaces of 40 lakes in the Austrian Alps in relation to environmental variables, and their potential for palaeoclimatology, J. Limnol., 63, 171-189, 2004.

Shindell, D. T., Schmidt, G. A., Mann, M. E., Rind, D., and Waple, A.: Solar forcing of regional climate change during the Maunder Minimum, Science, 294, 2149-2152, 2001.

Šmilauer, P. and Lepš, J.: Multivariate analysis of ecological data using CANOCO 5, Cambridge University Press, Cambridge, 2014.

Smol, J. P., Wolfe, A. P., Birks, H. J. B., Douglas, M. S., Jones, V. J., Korhola, A., Pienitz, R., Rühland, K., Sorvari, S., Antoniades, D., Brooks, S. J., Fallu, M. A., Hughes, M., Keatley, B. E., Laing, T. E., Michelutti, N., Nazarova, L., Nyman, M., Paterson, A. M., Perren, B., Quinlan, R., Rautio, M., Saulnier-Talbot, E., Siitonen, S., Solovieva, N., and Weckström, J.: Climate-driven regime shifts in the biological communities of arctic lakes, P. Natl. Acad. Sci. USA, 102, 4397-4402, 2005.

Solanki, S. K., Usoskin, I. G., Kromer, B., Schüssler, M., and Beer, J.: An unusually active sun during recent decades compared to the previous 11,000 years, Nature, 431, 1084-1087, 2004.

Stebich, M., Rehfeld, K., Schlütz, F., Tarasov, P., Liu, J., and Mingram, J.: Holocene vegetation and climate dynamics of NE China based on the pollen record from Sihailongwan Maar Lake, Quat. Sci. Rev., 124, 275-289, 2015.

Tan, L., Cai, Y., An, Z., Yi, L., Zhang, H., and Qin, S.: Climate patterns in north central China during the last $1800 \mathrm{yr}$ and their possible driving force, Clim. Past, 7, 685-692, https://doi.org/10.5194/cp-7-685-2011, 2011.

Tan, L., Cai, Y., Cheng, H., Edwards, E. R., Gao, Y., Xu, H., Zhang, H., and An, Z.: Centennial- to decadal-scale monsoon precipitation variations in the upper Hanjiang River region, China over the past 6650 years, Earth Planet. Sc. Lett., 482, 580-590, 2018.

Wang, H., Song, Y., Cheng, Y., Luo, Y., Gao, Y., Deng, L., and Liu, H.: Mineral magnetism and other characteristics of sediments from a sub-alpine lake ( $3080 \mathrm{~m}$ asl) in central east China and their implications on environmental changes for the last 5770 years, Earth Planet. Sc. Lett., 452, 44-59, 2016. 
Wang, Y., Cheng, H., Edwards, R. L., He, Y., Kong, X., An, Z., Wu, J., Kelly, M. J., Dykoski, C. A., and Li, X.: The Holocene Asian monsoon: links to solar changes and North Atlantic climate, Science, 308, 854-857, 2005.

Wanner, H., Mercolli, L., Grosjean, M., and Ritz, S. P.: Holocene climate variability and change: a database review, J. Geol. Soc. Lond., 172, 254-263, 2014.

Williams, D. M. and Round, F. E.: Revision of the genus Fragilaria, Diatom Res., 2, 267-288, 1987.

Yan, L. and Liu, X.: Has climatic warming over the Tibetan Plateau paused or continued in recent years?, J. Earth Ocean Atmos. Sci., 1, 13-28, 2014.

Yang, W., Yan, Y., Zhang, Y., Guo, W., and Zha, F.: Geoheritages in the Qinling Orogenic Belt of China: Features and comparative analyses, Geol. J., 53, 98-413, 2018.
Zhang, Y., Sperber, K. R., and Boyle, J. S.: Climatology and interannual variation of the east Asian winter monsoon: Results from the 1979-95 NCEP/NCAR reanalysis, Mon. Weather Rev., 125, 2605-2619, 1997.

Zhang, Y. B., Wang, Y. Z., Phillips, N., Ma, K. P., Li, J. S., and Wang, W.: Integrated maps of biodiversity in the Qinling Mountains of China for expanding protected areas, Biol. Conserv., 210, 64-71, 2017.

Zhou, A., Sun, H., Chen, F., Zhao, Y., An, C., Dong, G., Wang, Z., and Chen, J.: High-resolution climate change in mid-late Holocene on Tianchi Lake, Liupan Mountain in the Loess Plateau in central China and its significance, Chinese Sci. Bull., 55, 2118-2121, 2010. 